http://dx.doi.org/10.5902/1984686X38114

\title{
Deaf children, humor and education policy
}

\author{
Crianças surdas, humor e política educacional \\ Niños sordos, humor y política educativa
}

\author{
Donna Jo Napoli \\ Professor of Swarthmore College, Pensilvania, United States of America. \\ donnajonapoli@gmail.com \\ ORCID - https://orcid.org/0000-0001-6320-1086

\section{Rachel Louise Sutton-Spence} \\ Professora na Universidade Federal de Santa Catarina, Florianópolis, Santa Catarina, Brasil. \\ suttonspence@gmail.com \\ ORCID - https://orcid.org/0000-0001-6575-9446
}

Recebido em 28 de maio de 2019

Aprovado em 22 de julho de 2019

Publicado em 22 de outubro de 2019

\section{ABSTRACT}

Deaf children need true inclusion to learn, entailing consistent, pervasive use of visuallearning techniques. This is achieved via bilingual education policies that enforce deaf children's rights to use sign language, permitting teachers to engage in deaf pedagogy using sign language. Educational policies advocating inclusion via an interpreter in the mainstreamed classroom create the "illusion of inclusion" (Glickman 2003). We argue that, in either case, humor can aid inclusion. Understanding humor is a developmental ability, related to cognitive, social, linguistic, and metalinguistic competence. Additionally, learning how humor is understood and expressed contributes to language mastery. However, we find little discussion of humor in deaf education. We contend that deaf students have the right to learn through humor and play, throughout school. Educational and linguistic rights policies should reflect that. Educators understand that games are important for learning at any age, and especially for the very young where play is learning, and learning is play. We offer examples of how to modify common classroom activities to extend their effectiveness to deaf children and enhance their effectiveness with hearing children, from dance making mathematical concepts visually apparent, through sign language play encouraging creativity, to mime and theatre techniques illustrating geological facts.

Keywords: Deaf education; Humor; Education policy; Language rights. 
http://dx.doi.org/10.5902/1984686X38114

\section{RESUMO}

As crianças surdas precisam de uma verdadeira inclusão para aprender, por um uso consistente das técnicas de aprendizagem visual. Isto é feito através de políticas de educação bilíngue com direitos linguísticos para usar a língua de sinais que permitem aos professores se engajar em pedagogia surda usando língua de sinais. Políticas educacionais que defendem a inclusão por meio de um intérprete na sala de aula integrada criam a "ilusão de inclusão". Defendemos que, em ambos os casos, o humor pode ajudar na inclusão. A compreensão do humor é uma habilidade de desenvolvimento, relacionada à competência cognitiva, social, linguística e metalinguística. Além disso, aprender como compreender e produzir o humor contribui para o domínio da língua. No entanto, encontramos pouca discussão sobre humor na educação de surdos. Nós afirmamos que os alunos surdos têm o direito de aprender através do humor e da brincadeira na escola. Políticas educacionais e de direitos linguísticos devem refletir isso. Os educadores entendem que os jogos são importantes para a aprendizagem em qualquer idade e, especialmente, para os mais novos, onde brincar é aprendizagem, e aprender é brincadeira. Oferecemos exemplos de como modificar as atividades em sala de aula para aumentar a eficácia com as crianças surdas e ouvintes, da dança tornando os conceitos matemáticos visualmente aparentes, usando a língua de sinais criativa, e técnicas de mímica e teatro para ensinar fatos geológicos.

Palavras-chave: Educação surda; Humor; Políticas educacionais; Direitos linguísticos.

\section{RESUMEN}

Los niños sordos necesitan una verdadera inclusión para aprender, por un uso consistente y generalizado de las técnicas de aprendizaje visual. Esto se hace a través de políticas de educación bilingüe que permiten a los profesores involucrarse en pedagogía sorda usando lenguaje de signos. Las políticas educativas que defienden la inclusión a través de un intérprete en el aula integrada crean la "ilusión de inclusión". Defendemos que, en ambos casos, el humor puede ayudar en la inclusión. La comprensión del humor es una habilidad de desarrollo, relacionada con la competencia cognitiva, social, lingüística y metalinguística. Además, aprender cómo comprender y producir el humor contribuye al dominio de la lengua. Sin embargo, encontramos poca discusión sobre el humor en la educación de sordos. Nosotros afirmamos que los alumnos sordos tienen el derecho de aprender a través del humor y la broma en la escuela. Las políticas educativas deben reflejar esto. Los educadores entienden que los juegos son importantes para el aprendizaje a cualquier edad y, especialmente, para los más jóvenes, donde jugar es aprender, y aprender es broma. Ofrecemos ejemplos de cómo modificar las actividades en el aula para aumentar la eficacia con los niños sordos y oyentes, de la danza haciendo los conceptos matemáticos visualmente aparentes, usando la lengua de signos creativa, y técnicas de mímica y teatro para enseñar hechos geológicos.

Palabras clave: Educación Sorda; Humor; Políticas Educativas; Derechos de Idioma. 
http://dx.doi.org/10.5902/1984686X38114

\section{Introduction}

We start with a quotation from Claudio Mourão, a deaf sign language artist, dancer, PhD and professor at UFRGS:

In my childhood I spent most of my life playing and so I discovered meanings of games, while the mouth was unknown ... At school the same happens between the mouth and play; all children and young people have the right to write, learn and play, while the deaf student continues to write as imitation / copy, learns little and spends many hours without interacting. (MOURÃO, $2011,36-37)^{1}$

In this article, we consider the role that language and educational policies play at the individual, institutional and state or federal level in the use of humor in a deaf child's education. Play and interaction with others (peers and teachers) are essential to education, yet their role in educating deaf children has been largely ignored. The quotation above captures this need for deaf children to play and learn. We argue that humor is essential for deaf children's overall educational experience, their academic performance and psycho-social health, and can easily be inserted into teaching at all levels to great effect, but that certain policy decisions can help or hinder its use, especially in relation to the linguistic choices.

Although the content of the material presented in the classroom is important for deaf education, we present evidence from within the framework of deaf pedagogy that it is also necessary to inject humor into interactive activities across the curriculum. Teachers with a deaf child among their students can implement our suggestion in any classroom immediately and without extra funding.

There is little in either institutional documentation or pedagogical literature that stresses or even mentions the value of humor to the educational development of deaf children, whether in a mainstream education environment in deaf schools. Thus, it is our task to make the case, using what little we have found, as well as materials outside pedagogy per se.

We first discuss educational policy with respect to deaf education at varying institutional levels, concluding that individual classroom teachers are most responsible for assuring a good academic experience for deaf children. Next, we turn to good practices noted by researchers on how deaf children learn, ending with the promotion of social interaction between deaf and hearing. Then we present our case for the value of humor as a means of creating social bonds in the mainstreamed classroom. Finally, we discuss 
http://dx.doi.org/10.5902/1984686X38114

ways to promote humorous interaction in the classroom. We consider three activities representative of classroom activities regardless of culture and country, in the areas of mathematics, literary arts, and science, and show how they can be infused with humor to create a better classroom atmosphere for the deaf child (and the hearing child). This better atmosphere may lead to improvement in the deaf child's academic and personal life.

\section{The problem}

Many deaf ${ }^{2}$ children do not do well at school, nor do they like it. Although there is a mass of evidence attesting to deaf children's poor academic performance in comparison with their hearing peers, there is low interest (judging by the dearth of scholarly articles) in their feelings about school. This is regrettable, especially since the two may well be connected.

With respect to poor academic performance, scholars note that many deaf children do not attain strong literacy skills and those that do typically take much longer to learn to read than hearing peers (HOFFMEISTER; CALDWELL-HARRIS, 20143). This fact holds globally, regardless of writing system (WANG; LEE; PAUL, 2010), and undoubtedly correlates to a range of large issues, including lack of support for schools in the form of overcrowding, insufficient teaching materials, and inadequate curriculum support (MAPEPA; MAGANO, 2018), as well as, and probably most important, poor early language access (CLARK et al., 2016). Deaf children have the linguistic right to enjoy education through the "Least Restrictive Environment" (JOHNSON et al., 1989, p. 18) which "is one in which they may acquire a natural sign language and through that language achieve access to a spoken language and the content of the school curriculum" (for more recent germane remarks see Cripps and Supalla 2012).

However, others disagree even on such a basic issue. Inclusion in the mainstream oral classroom, sometimes with the aid of note-takers and/or interpreters is taken to be the least stigmatizing form of education by many and is educational policy in some countries even in the face of poor academic outcomes (TAKALA; SUME, 2018; LAU et al., 2019). Unfortunately, such disagreement means that teachers feel unsure of what practices to implement in the classroom within whatever constraints set upon them by their institutions (SWANWICK; MARSCHARK, 2010). 
http://dx.doi.org/10.5902/1984686X38114

Addressing these large issues in order to bring about the best environments for deaf children in bilingual schools or in mainstreamed situations requires concerted and coordinated effort on the part of all the interested parties --governmental, educational, and medical professionals, as well as families and the larger community.

\section{Educational policy, deaf teachers and deaf children}

Some countries have no national educational policy. In the United States for example, education is the responsibility of state government, local government, and parents. While sometimes educational initiatives are widely adopted by states (such as the Common Core State Standards Initiative ${ }^{3}$ of 2010), there is a great deal of variation in how they implemented. There is no common national policy on how to educate deaf children, although the Individuals with Disabilities Education Act (IDEA, last amended in 2004; https://sites.ed.gov/idea/) authorizes special education for children with disabilities including deaf children. That special education, however, does not recognize their linguistic right to sign language in bimodal-bilingual education.

Other countries have national educational policies, carried out in a standard way across the country. In Brazil, for example, every twenty years there is a review of the policies, and changes can be made. The most recent Plano Nacional de Educação was implemented in 2014 (http://pne.mec.gov.br/18-planos-subnacionais-de-educacao/543plano-nacional-de-educacao-lei-n-13-005-2014). The part pertaining to deaf education is in Meta 4.7, guaranteeing the linguistic rights of deaf Brazilian children to an education in Libras and written Portuguese until the age of 17 :

4.7) guarantee to offer bilingual education, in Brazilian Sign Language LIBRAS as the first language and in the written form of Portuguese as a second language, to deaf and hearing impaired students from 0 (zero) to 17 (seventeen) years, in schools and bilingual classes and in inclusive schools, according to art. 22 of Decree No. 5,626, dated December 22, 2005, and arts. 24 and 30 of the Convention on the Rights of Persons with Disabilities, as well as adoption of the Braille reading system for the blind and deaf-blind people; ${ }^{4}$

However, even in this clearly defined right to bimodal-bilingual education, there is little documentation as to how such a right is to be delivered. Certainly, recent national priority has been for inclusion and mainstreaming, and scholars are working on helping develop bilingual education policies (QUADROS; STUMPF in press; QUADROS 2018; 
http://dx.doi.org/10.5902/1984686X38114

GUIMARÃES; FINARDI; CASOTTI, 2019), but until such language rights policies are established, there can be great variation in what goes on in each classroom.

The result is that the responsibility of providing deaf children an appropriate education lies with the individual classroom teachers, both in countries with no uniform policy, like the United States, and in countries with a strong uniform policy, like Brazil. Individual teachers create (or not) an accessible learning environment for deaf children (ANTIA et al., 2009). This does not mean that teachers must develop special curricula for deaf children but rather that they need to find ways to make the existing curricula "work" for the children (ALASIM; PAUL, 2018); they need to use good practice in deaf education, as we discuss in the next section.

\section{Deaf Pedagogy}

Deaf pedagogy is an educational, cultural and historical approach to teaching that transmits the traditional values of deaf people to other deaf people (PERLIN; STROBEL 2008; LADD, 2011). Deaf pedagogy emphasizes to a deaf child what 'being deaf' means, in terms of deaf identity, sign language and deaf cultural values. This understanding of the deaf self occurs when a deaf child is in presence of another deaf person, and within deaf pedagogy, the encounter with deaf adults makes the process of identification possible for deaf students (GONZALEZ, 2017). Even in bilingual schools, many teachers are not deaf. Gonzales (2017, p. 214) suggests that this can be explained in part by policy-makers' lack of awareness of the "relevance of the Deaf educators to Deaf students' holistic development, and also, about their contributions to the school community and their families". However, education and language policies also need to recognize the specific role that deaf educators can play in schools, whether as teachers or learning assistants.

The educational policy with the most impact on deaf children's education is that which determines whether they are mainstreamed or educated in a bilingual school with their deaf peers. Those educated bilingually have a greater likelihood of having a deaf teacher and these teachers are likely to display aspects of deaf pedagogy. Thus deaf pedagogy and the linguistic right to sign language in education are tightly bound. Mainstream education policies that do not bring deaf children into contact with each other, or with deaf adults, deny deaf pedagogy the space it needs, even to the extent of 
http://dx.doi.org/10.5902/1984686X38114

preventing deaf adults from understanding how to be deaf pedagogues for the next generation (LADD; GONÇALVES, 2012, p. 29-30). ${ }^{5}$

Even education policies that promote sign language and deaf educators as linguistic and cultural models do not necessarily promote deaf pedagogy if they do not include deaf cultural principles and practices in the curriculum (PERLIN; STROBEL, 2008). The policy of educating deaf children in regular, mainstream schools denies them the opportunity of benefitting from deaf pedagogy, if teachers are not aware of the changes that they can make to their teaching practices.

Although we have found so little written about humor in research on education of deaf children, humor is repeatedly mentioned as a significant aspect within deaf pedagogy. Published research and our own discussions with deaf teachers have shown that children enjoy their signed lessons, especially signed stories, because they are funny.

Gonzales (2017) notes that Deaf educators create learning opportunities as part of their deaf pedagogical practices, that their students can recognize and respond to their group and individual needs, including the need for fun as part of their learning. She quotes a Deaf co-educator working with pre-school children who described a physical game in which she wrapped the children inside the carpet and then they roll for fun, saying:

I cannot force them to do long things (activities that take a lot of time), and
then tell them 'you have to pay attention'. No, if they do not want more,
nothing more. Another day we would be back to that (...) I tell them 'we are
going to do something different (expression of thinking) a short story or a
short game, first help me to separate the tables...' It is like resting because
they have been working, working, working during the day. I do not know
how they worked before, the teacher worked and worked (Ed. 8).
(GONZALEZ, 2017, p. 172)

Where deaf schools have a policy of allowing space in the curriculum for sign language study, there is a greater opportunity for sign language storytelling, language play and the humor that goes with it. Deaf teachers we have worked with in the UK and the USA have told us that they have protected time in the curriculum. One school in California had lesson every Friday called "Art/ASL hour" in which deaf teachers could teach about creative signing, much of it humorous and entertaining for the children. Paul Scott, a British deaf teacher, described Deaf Studies lessons, in which they learn about sign language and storytelling (SCOTT, 2011). He showed the children amusing cartoons about the problems of deaf life - and how to solve them. WEST (2011) quotes a deaf child from Paul Scott's classroom who had experienced him telling them a story about deaf 
http://dx.doi.org/10.5902/1984686X38114

ingenuity and asking them to work out a solution to the same problem, and who mentions, almost in passing, that it was funny: "we all had to think really hard what the answer was...And in the end he explained to us what happened in the story, and it was so funny, we were all laughing, we love that! So much fun!" (WEST, 2011, p. 370).

Gonzales (2017) also describes Chilean deaf teachers' use of humor, commenting on the close relationship between language creativity, embodied performativity of signing and humor. She observed several situations in her fieldwork in which fun formed a fundamental part of classroom activities. She remarks:

The class went on smoothly. The children were engaged in the class, all of them participated. How the educator applied humour got my attention. Instead of telling explicit jokes, he used the same topic of the class and explained the contents in a funny way. (GONZALES, 2017, p. 249).

In these descriptions, several important points are revealed. First, the importance of sign language in humor. Second, humor brings an important togetherness and sense of sharing in the learning experience. The teachers and children cooperate in creating both the humor and the whole learning activity. In descriptions of various activities (such as acting out a baseball game played by the Three Little Pigs for younger children and explaining mayoral elections for older children), the teacher takes a role in acting out a narrative with the children and they laugh together. Despite the fun and laughter (or perhaps because of it), Gonzales notes that the children were "attentive". This shared humor lets children practice teamwork, communicating and interacting with each other, and with adults. Third, the humorous and fun activities encourage independence as humorous activities led to the children developing their own independent creative activities. After acting out the baseball game, Gonzales explains that the children went on to make their own game.

Other uses of humor involve the deaf teacher acting naively and expecting the students to correct their mistakes to help them participate and engage in the topic. Younger children enjoy incongruity (LUCKNER; YARGER, 1997) and laugh at situations which they know to be "wrong", so a teacher who says things that are patently incorrect is amusing. This use of humor encourages the students to focus and learn (in the example Gonzales describes, the lesson is about the body, and they learn new signs and words about the body), but the situation also lets the children show their own knowledge to their teacher and peers and teaches them responsibility for helping others to learn. Finally, 
http://dx.doi.org/10.5902/1984686X38114

humor in sign language can reach deaf children with cognitive problems who have specific communication needs. Gonzales observed a Deaf educator working one-on-one with such a deaf child, who used a range of methods to facilitate communication, including humor and signing using embodied actions, described for the other deaf children.

\section{Good practice in deaf education}

Successful reading in deaf children appears to use more top-down strategies than bottom-up strategies, thus Andrews and colleagues (2016) argue that such strategies are part of good practice in the mainstreamed classroom. The alternatives they propose concentrate on gaining visual attention so that learning can proceed via vision, including fingerspelling (argued for cogently way back in Padden and Ramsey 1998) and signing, which the mainstreamed classroom teacher might not be able to manage, but also the use of drawings and other kinds of illustration, plus movies and other kinds of visual media (KUNTZE; GOLOS; ENNS, 2014), which any teacher can manage.

Simply teaching children understanding of print can help give the big picture of what books are all about; thus paging through an illustrated book, even one without print at all (such as Frog, where are you?), can teach the child where to begin and how to proceed through the book. Having the child tell a story and then draw pictures that support it and organize them in an order that correlates to the story plot can help children develop knowledge of narrative structure. All these activities appeal to both deaf and hearing children.

Important in all this is the behavior of the individual teacher - that person that we identified in the last section as being the one most responsible for the education of the deaf child. First, she can practice consistent, pervasive use of visual-learning techniques (HAUSER et al., 2010; SKYER, 2018), as deaf parents know, witness their visually-based practices (BERKE, 2013). She must integrate these visual-learning techniques into the classroom in multiple ways (PAUL et al., 2013), including the use of smart boards and the Internet (BERNDSEN; LUCKNER, 2012; ERBAS, 2017). If she is so inclined, she can avail herself of the richness that YouTube offers in the way of presenting Deaf Culture, encouraging students to mimic stories, such as those of the Teatro Alegria Surda (PINHEIRO, 2011) and RISE (MIRUS; NAPOLI, 2018). Silveira and colleagues (2011) suggest that she bring to the inclusive classroom stories in Deaf Culture that focus on joy, 
http://dx.doi.org/10.5902/1984686X38114

love, and optimism, with illustrations of smiling characters. Such stories help develop deaf identity (SUTTON-SPENCE, 2010) and can help all children who are dealing with dilemmas, uncertainty, and ambiguity, as some deaf children are (for a retrospective from deaf adults' point of view, see KUSHALNAGAR et al., 2017). Holcomb (2011) argues that presenting deaf stories offers the deaf child relief from the constant oppression of speechoriented perspectives; and, of course, that means giving the hearing child the advantage of seeing a sign or visual-oriented perspective. And for the older child, the teacher can present deaf movies to inform hearing and deaf about the life of a deaf person in a hearing world (THOMA, 2011).

Second, she must treat deaf and hearing students equally with respect to expectations of what they can achieve. Certainly, the deaf child has special needs which must be met in order to acquire literacy, but if those needs are met, the teacher should expect good academic performance by the deaf child, which the child is then more likely to achieve (JOHNSON; LIDDELL; ERTING 1989).

Third, she must provide opportunities for social and academic interaction between deaf and hearing people in the classroom. Extensive social interaction and friendship at school are of critical importance to the development of all children, affecting self-esteem (BISHOP; INDERBITZEN 1995), and leading to positive attitudes toward school (TOMADA et al., 2005), while the lack of it is indicated in anxiety and depression (LAURSEN et al., 2007) and in both disliking school and performing poorly academically (FLOOK; REPETTI; ULLMAN, 2005).

Deaf children are like hearing children in this regard. Having a healthy deaf identity is a complex of factors (Leigh, 2017), and, unsurprisingly, social interactions among other deaf individuals is paramount (CARTER; MIRELES, 2016). Nevertheless, feeling included socially and academically in a mainstream classroom (the kind of classroom most deaf children in the world experience if they go to school at all) is important, where those who do not feel so included are less satisfied with their lives (OLSSON; DAG; KULLBERG, 2018). A meta-study of factors correlating to the success of a mainstreamed education includes friendships in the list of nine most important ones. ${ }^{6}$ Unfortunately, most (but not all) mainstreamed deaf students experience barriers both in making friends and in participating in social activities (BATTEN; OAKES; ALEXANDER, 2014; XIE; POTMESIL; 
http://dx.doi.org/10.5902/1984686X38114

PETERS, 2014). When such friendships are made, hearing children develop positive attitudes toward deaf children (HUNG, 2005), which, in turn, leads to more friendships.

It is this third obligation that we focus on here, suggesting that the teacher can best fulfill it by infusing humor in the classroom, as we argue below.

\section{Humor and inclusion}

Understanding humor is a developmental ability, related to cognitive, social, linguistic, and metalinguistic competence. Additionally, learning how humor is understood/ expressed contributes to language mastery and to understanding of the material the humor is based on (HUSS 2008), even up through higher education (GARNER, 2006). And, perhaps most important, humor changes the atmosphere of the classroom and can make it more inclusive, as we argue below.

Deaf children's understanding of humor has been studied and encouraged in a variety of ways. Luckner and Yarger (1997) studied responses to cartoons, noting differences in reactions between deaf and hearing students. Sanders (1986) studied humor produced and appreciated by deaf children. Ashton and colleagues (2012) argue that deaf children should be taught to appreciate humorous deaf literature and to understand that hearing and deaf people have different notions of what is funny. In their suggestions for 4th grader activities, they include watching ASL cartoons and humorous skits. In 8th grader activities, they include presenting humorous stories and watching humorous anecdotes by deaf performers and they stress the importance of understanding well-known humorous ASL stories. In 12th grader activities, they suggest viewing ASL jokes and humorous stories. These suggestions are well-taken, given that humor, particularly humor based on playing with the linguistic structure of sign languages, plays a special bonding role in deaf communities (SUTTON-SPENCE; NAPOLI, 2009).

Yet, despite the fact that many educators know that humor is related to happiness and a happy teacher can lead to happier students (NILSEN, 2019), no one, so far as we know, has focused on the social role that humor can play in the mainstream classroom with respect to deaf children and how that role can positively impact academic achievement and psychosocial health. In fact, no one even mentions humor in this regard (and note the absence of it in entire books, such as Cawthon and Garberoglio, 2017). 
http://dx.doi.org/10.5902/1984686X38114

Mainstreamed deaf children have much more limited interactions with their hearing peers than the hearing children do with each other (KEATING; MIRUS, 2000). Indeed, studies reveal the loneliness that deaf children feel (NUNES; PRETZLIK; OLSSON, 2001; ELHAGEEN, 2004; MOST, 2007; MOST; INGBER; HELED-ARIAM, 2011). When deaf adults look back on their childhood, they remember suffering from loneliness (LEVINGER; ORLEV, 2008), and Kurz, Hauser, and Listman (2016, p. 88) note that deaf people "are faced with lack of access to the emotional lives of others, reduced experiences of empathic communication, and constant social experiences of isolation, all of which are risk factors that most likely make them less resilient".

Laughter, we propose, can help change that. Laughter in the classroom builds relationships and fosters teamwork, improves classroom instruction, makes a culture out of a classroom, relieves tension, promotes creativity, can lead to more cooperative student behavior and can even help teachers stay interested in their work (JONAS, 2009). Spontaneous laughter creates friendship bonds, partly because it is a social experience connected to cooperative interaction and friendship (FLAMSON; BARRETT, 2008; KURTZ; ALGOE, 2015).

Activities that cause spontaneous laughter are exactly what the deaf child needs in order to feel truly included in school and to make friends. Thus, educational policies should ensure that deaf students have the right to learn through humor and play throughout school. Educators understand that games are important for learning at any age, and especially for the very young where play is learning, and learning is play.

\section{Humor across the curriculum}

There is already a move to promote humor study in Brazil. With regard to the graphic arts, in April 2019, the Centro Nacional de Humor Gráfico, through the Secretaria de Ação Cultural e Turismo de Piracicaba, in partnership with the Diretoria Regional de Ensino de Piracicaba, Secretaria de Educação de Piracicaba, and SESC Piracicaba, conducted two workshops to train art teachers of children and adolescents on how to present humorous design in the classroom 7 . Their focus is on comics and caricatures, and teaching humor in two- and three-dimensional design.

Our point, however, is that humor should be infused in teaching across the curriculum, where that humor pervades and often erupts as part of the participatory 
interaction of the students. We now offer examples of how to modify common classroom activities to extend their effectiveness to deaf children and enhance their effectiveness with hearing children. While we elaborate on only one example in three different subjects, we hope our discussion will help spawn ideas in teachers to modify other classroom activities.

\section{Mathematics}

School-age children perform better on tasks that call for mathematics skills and on tasks of numerosity perception if they can allocate and maintain visual spatial attention (ANOBILE; STIEVANO; BURR 2013). One activity that requires, and, therefore, develops sustained visual spatial attention is dance, particularly dance with a partner (SEBANZ; BEKKERING; KNOBLICH, 2006). The constraints involved in coordinating movement over shared space command joint attention to time and space, with consideration of the predictors of actions of the partner (SEBANZ; KNOBLICH, 2009; SCHMIDT; RICHARDSON, 2008). Thus, dance activities seem like a natural basis for teaching mathematics within the limitations of students' physical mobility.

In fact, Schaffer, Stern, and Kim (2001) as well as Schaffer (2012; 2014) explain how dance can teach patterns and creative problem solving, both essential to mathematics performance. Rosenfeld (2016) outlines a range of dance activities that help children learn mathematics concepts and problem solving. She demonstrates some of her activities on a video (ROSENFELD, 2013), from which we have made screen shots to illustrate our points (Figure 1).

Rosenfeld draws squares on the floor and each child dancer starts with a square to stand within.

In order to demonstrate reflexive symmetry (Figure 1A), the children jump with both feet to one side, then the other, and to the front edge (not shown in our figure), then to the back edge. But they coordinate and jump toward each other or away from each other when they go to the sides, and both jump to the back together or to the front together. Thus, they stay in a relationship of reflexive symmetry with respect to the axis that divides their two squares on the floor.

In order to demonstrate parallel structures (or translational symmetry) with respect to diagonals (Figure 1B), the children jump with one foot to the ipsilateral front corner and the other foot to the diagonally opposite ipsilateral back corner. Then repeat, starting with the 
http://dx.doi.org/10.5902/1984686X38114

other foot. Both use the same foot to start with (right or left). They can then try jumping with one foot to the contralateral front corner and the other foot to the diagonally opposite contralateral back corner.

Once demonstrations have been done, all the children pair up and practice (Figure 1C). They work with concentrated effort, trying not to bump into each other. And when they succeed, it is a joyful moment - a moment of spontaneous laughter.

Figure 1 - Dance-math activities

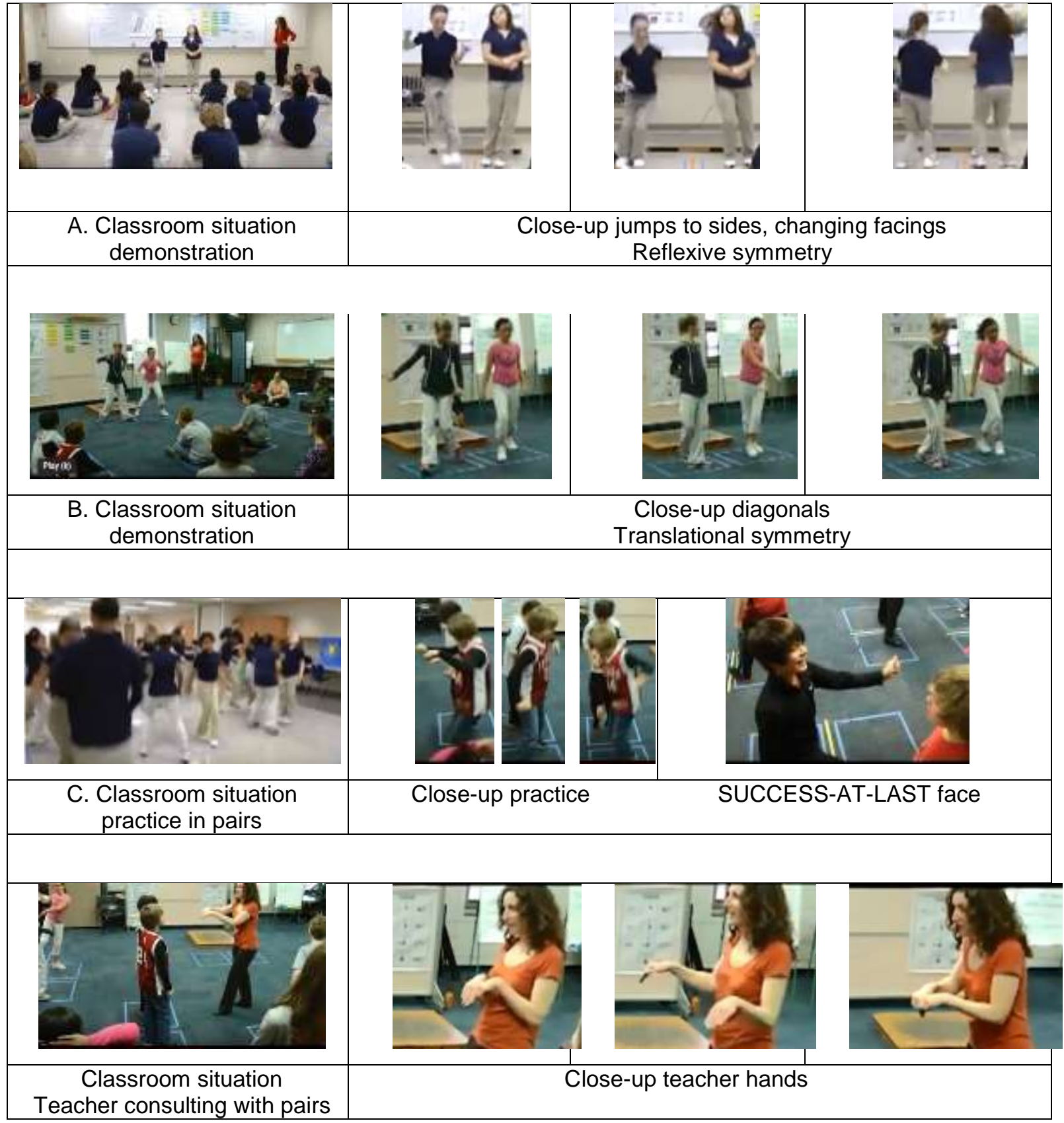

Source: The authors, based on images from Rosenfield (2013). 
http://dx.doi.org/10.5902/1984686X38114

This is a wonderfully interactive activity that asks the children to interact in an essentially playful way. And it is particularly appropriate because it uses the body - so it teaches multimodally, which means it automatically has a greater chance of making sense to more children. Additionally, teachers could adapt the activities for children with restricted mobility. It can be carried a step further; in Figure 1D the teacher explains what the feet should do by using her hands to demonstrate. Here's where humor can be used. This shift to the hands increases the chances of spontaneous laughter occurring throughout, and not just when there is a success-at-last moment. Other shifts could also be explored.

The children could sit at a table and do the exercises with their hands in squares drawn on the table. (Or the students could be encouraged to get on their knees and do the exercises with their hands on the floor.) They could try doing them with their elbows. Variations could involve using an ear and the opposite hand, the chin and either hand, or the forehead and either hand. The twisting involved can allow for discussions of physiology and biomechanics. And assuredly it will lead to feeling silly and happy, with plenty of spontaneous laughter.

Such activities don't require access to sound or sign language. This means deaf children can contribute to the joint venture as richly as any other child. In fact, deaf children who sign have enriched spatial cognition (BELLUGl et al., 1990), so a hearingdeaf partnership might even have an edge over hearing-hearing partnerships. Imagine the joy of the deaf child who is a favored choice as a partner because of an enhanced ability. Such a deaf child might have a more positive attitude toward school and learning.

\section{Sign language, humor and Storytelling}

Language rights policies that accept sign languages as the language of instruction see them as a tool for access to education, and sign language has been shown repeatedly to be the language that allows a deaf child to understand what the teacher is saying. Additionally, it must be the language that deaf children use to interact with others and express themselves freely. Rarely noted, though, is that sign language is a source for play. All children play with language and deaf children have the right to play with their sign language. Paul Scott, a British deaf poet and teacher, remarked of the children in his class 
http://dx.doi.org/10.5902/1984686X38114

"They love playing with language and thinking about linguistic ideas. Moreover, it is of great benefit to them" (SCOTT, 2011, p. 360).

As Karen Christie, an American deaf educator and researcher noted "I can play with language. I can be creative with it. I don't have to just communicate, you know, just get by with basic communication. I can express myself and I can take in what others express" (CHRISTIE in NATHAN LERNER; FEIGEL, 2009, minute 00:04:32).

In a duet poem in American Sign Language by Peter Cook and Kenny Lerner, the performers play with their sign language in a creative and humorous way to create this message about the realization that deaf people can have when they are introduced to sign language literature:

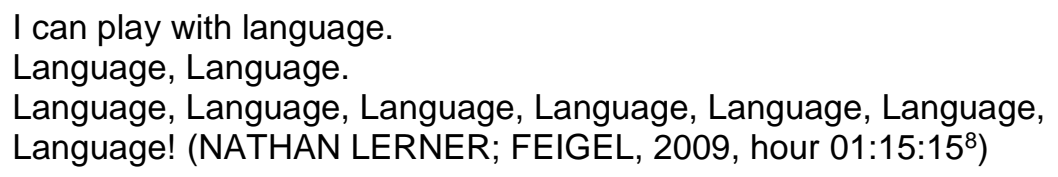

Deaf teachers in the USA and UK who work within deaf pedagogy know that laughter in the classroom is indispensable for learning (BORK; GUNNARSDOTTIR, 2001). They play with sign language as part of their approach to teaching and thereby create a visual language learning environment for deaf children that is entertaining and makes learning fun. This is especially true when telling stories, bringing the widespread deaf understanding that stories should be fun (e.g. HALL, 1989; PETERS, 2000; SUTTON-SPENCE; NAPOLI, 2009).

Sutton-Spence and Ramsey (2010) report a deaf teacher's view that signed stories should be funny, saying "Yes, you can take the facts and elaborate on them and make that into a story. Yes, yes. ... because the kids are so engaged with it. If it's a boring story they're just kind of stuck there but I like to add a little flavor to it".

This flavor of humor is so crucial. Ladd notes that deaf educators help their pupils

to appreciate the plasticity and beauty of their language - indeed to actively understand that it is their language. Thus, some of the educators we observed were particularly skilled at encouraging sign play and creative signing, emphasizing the importance of storytelling. (LADD, 2011, p. 377)

Deaf pedagogues are aware that humor needs to be used and controlled appropriately. Sutton-Spence and Ramsey (2010) report a teacher's view that storytelling in sex education could be for talking about serious facts (such as a person who became ill 
or pregnant) but that creative, performative, amusing storytelling would probably just end up with the children being "silly".

Once the teachers have captured children's attention and generated a relaxed atmosphere in the classroom, they can build upon the humor for more serious learning outcomes. Ladd and Gonçalves (2012) also described humor as a useful strategy employed by teachers to help deaf children cope with the difficulties they face when living in deaf and hearing cultures.

Deaf pedagogues in the bilingual classroom can use humor in sign language to help children understand how their visual language works (SUTTON-SPENCE; RAMSEY, 2010), but the reality in mainstream classrooms is that neither the teacher, nor the nonsigning class-mates of a deaf student knows any sign language. This need not be a problem, however, because the humor of many sign language artists does not demand knowledge of any sign language but draws on visual communication skills that everyone can use and appreciate, giving hearing students a new perspective on what they understand by communication, language and literature. This is a form of Deaf Gain, as described by Bauman and Murray (2014), which contrasts to the idea of Hearing Loss, showing how deaf creativity can inform and extend ideas that hearing people have about literature and language creativity (SUTTON-SPENCE, 2014).

There are some types of sign language literature that go beyond the vocabulary of the language to produce highly visual imagery using Visual Vernacular, a technique that blends mime with sign language (BRAGG in NATHAN LERNER; FEIGEL, 2009; SUTTONSPENCE; BOYES BRAEM, 2013). Where the piece is completely visually transparent, all students and teachers can enjoy it and appreciate it for its story structure, and for the way it is told. Stefan Goldshmidt's humorous piece The Golf Bal${ }^{\beta}$ tells the story of a game of golf from the perspective of the ball. Most of the story is told through head movement and eyegaze, and everyone, deaf or hearing, signing or non-signing, will enjoy such a story, creating an inclusive atmosphere. Other highly visual stories are easily accessible and entertaining, with the minimum of explanation about the context. With minimal headnotes to give the context of the signs, for example, Sandro Pereira's humorous piece, The Bal/10, can be enjoyed by an entire class, who can all be encouraged to retell the chase sequence in the story and learn a lot about language, movement and the role of the body in communicating. Multiple texts with visual images are another support for teachers who 
http://dx.doi.org/10.5902/1984686X38114

have deaf pupils. Dack Virnig's split screen renditions of films in ASL are entertaining for deaf and hearing people (for example the Flamingo sequence from Fantasia ${ }^{11}$ ) as they show film images and signs simultaneously so that people can understand what is being signed while appreciating the rich complexity and potential of highly enjoyable creative signing. In all these examples, deaf and hearing children can access the same material and hearing children can interact with deaf children through humorous use of accessible signing.

\section{Science}

Humor and sign language can be brought to any subject area, including science. An example is given by the deaf American teacher Robert Weiniger in Sutton-Spence and Ramsey (2010) and described in more detail here. He describes a lesson concerning a volcano ring of fire where laughter is actively built into the metaphor. The teacher is in the center and the children are in a ring around him. These are 5th and 6th grade children. The teacher explained clearly that to help the children remember better "if you act things out and elaborate on it that way then it's much more notable... It's science but it's also creative signing."

To describe volcanos and the Ring of Fire, he described how he arranged his students in a semicircle around him and sat in the middle with his arms over his head, essentially becoming the volcano. His head was inside the volcano, situating the being of the volcano inside the mountain, to give it a sense of autonomy and volition. He asked the children to copy him and pretend they were also mountains. copying what he did, acting out the role of the volcano in the metaphor he presented by lifting his hands apart as though opening a lid and saying "boop!" to release the gases.

The children copy his acting out of the volcano and learn how to perform this style of creative anthropomorphic signing that is a key part of sign language creativity.

However, the humor and metaphor he developed continued, as he recounted: "Then they all start to laugh and can barely hold it in, and I say 'No, don't laugh.' I say, 'no it's the same with a volcano'. They can't control themselves and then just burst open as they laugh."

Because he tells them not to laugh, he builds up the pressure inside the children, like the pressure builds up inside the volcano Thus, the lesson creates a link of form and 
http://dx.doi.org/10.5902/1984686X38114

meaning through metaphor, as the idea of bursting open to let pressure out is mimicked in different signs of the volcano "lid" opening or their hands opening to let the laughter out, while they too experience the buildup of pressure until they have to let their laughter out.

He then offered an alternative story:

If you eat the wrong food and you stuff it down and it goes into your stomach and maybe your stomach gets a little bit upset and you have gas. It goes out and then you feel better. It's the same with the volcano. The volcano has gas and once it releases it, it feels a lot better. (SUTTON-SPENCE; RAMSEY 2010, p. 173)

Again, this is visually very strong as he anthropomorphizes the volcano, both conceptually and linguistically to get the metaphor across. He used the same signs to show the gas building up and the lava flowing down the volcano's slopes and to show the gas in a stomach and when breaking wind.

Once they have taken part in the shared, creative, funny theatrical story, they settle down together to discuss and synthesize what they learned, talking about pressure and exploding. It is a sound science lesson, made a lot funnier and more memorable by a burping, farting volcano.

Such a theatrical technique, while stemming in this case from the deaf teacher's visual senses and sign language skills, could also be used by non-signers - teachers and pupils. The whole class can participate in the theater, learning the same metaphors through the same physical, embodied experience.

\section{Conclusion}

This review of education research has shown that humor is important in the classroom for all children. We have presented evidence from more limited research to support our claim that deaf children can, and should, benefit from it. Arguments from deaf pedagogy propose that educational policies that promote inclusion rather than bilingualism threaten deaf children's access to important elements of deaf culture that enable them to learn what is necessary for developing a healthy identity as a deaf person, but policies determining the deaf child's linguistic right to sign language in class work towards it. We have brought evidence from research that humor is an important part of deaf pedagogy. However, the examples we have provided of individual teachers' practice, demonstrate that humor can be created in any classroom, whether mainstream or in a deaf school, whether the main language of instruction 
http://dx.doi.org/10.5902/1984686X38114

is the spoken or the sign language. Any teacher at any school in any subject area, with an eye to activities that are physical and visual rather than relying on the spoken or written word can use humor to benefit deaf pupils. Not only can this be done without cost to the teacher or the hearing classmates, it can directly benefit them. Shared laughter will lead to shared learning.

\section{References}

ALASIM, Khalid; PAUL, Peter. Inclusion and d/Deaf and hard of hearing students: A qualitative meta-analysis. The International Journal for Interdisciplinary Studies 8.2 p. 419. 2018.

ANDREWS, Jean; HAMILTON Beth; MISENER DUNN Kim; CLARK Diane. Early reading for young deaf and hard of hearing children: Alternative frameworks. Psychology 7, no. 04, p. 510-522, 2016.

ANOBILE, Giovanni; STIEVANO, Paolo; BURR, David. Visual sustained attention and numerosity sensitivity correlate with math achievement in children. Journal of Experimental Child Psychology 116.2: p. 380-391. 2013.

ANTIA, Shirin; JONES, Patricia; REED, Susanne; KREIMEYER Kathryn. Academic status and progress of deaf and hard-of-hearing students in general education classrooms. The Journal of Deaf Studies and Deaf Education 14.3: p. 293-311. 2009.

ASHTON, Glenna et al. Standards for learning American Sign Language: A project of the American Sign Language Teachers Association. 2012. Available for download from https://aslta.org/wp-content/uploads/2014/07/National_ASL_Standards.pdf. Accessed January 2019.

BATTEN, Georgina; OAKES, Peter; ALEXANDER, Tim. Factors associated with social interactions between deaf children and their hearing peers: A systematic literature review. Journal of Deaf Studies and Deaf Education, 19(3), p. 285-302. 2014.

BAUMAN, Dirksen; MURRAY, Joseph. (eds). The New Normal: Deaf Gain and the Future of Human Diversity. Minneapolis: University of Minnesota Press, 2014.

BELLUGI, Ursula; O'GRADY, Lucinda; LILLO-MARTIN. Diane; O'GRADY HYNES; VAN HOEK, Karen; CORINA, David. Enhancement of spatial cognition in deaf children. In VOLTERRA, Virginia; ERTING, Carol (eds), From gesture to language in hearing and deaf children, Berlin, Heidelberg: Springer. 1990. p. 278-298.

BERKE, Michele. Reading books with young deaf children: Strategies for mediating between American Sign Language and English. Journal of Deaf Studies and Deaf Education 18.3: 299-311. 2013. 
BERNDSEN, Maura; LUCKNER, John. Supporting students who are deaf or hard of hearing in general education classrooms: A Washington State Case Study. Communication Disorders Quarterly 33.2: 111-118. 2012.

BIENVENU, Martina (MJ). Reflections of Deaf Culture in Deaf Humor. In The Deaf Way: Perspectives from the International Conference on Deaf Culture, (eds.) ERTING Carol J.; JOHNSON, Robert C.; SMITH, Dorothy L.; SNIDER, Bruce D. Washington, DC: Gallaudet University Press, 1994. p. 16-23.

BISHOP Julia; INDERBITZEN Heidi. Peer acceptance and friendship: An investigation. Journal of Early Adolescence 15, 476-89.1995.

BORK, Alfred.; GUNNARSDOTTIR, Sigrun. Tutorial Distance Learning: Rebuilding Our Education System (Innovations in Science Education and Technology), New York: Kluwer Academic/Plenum Publishers, 2001.

BRYANT, Gregory. et al. Detecting affiliation in colaughter across 24 societies. Proceedings of the National Academy of Sciences 113, no. 17: p. 4682-4687. 2016.

CARTER, Michael; MIRELES Danielle. Deaf identity and depression. New directions in identity theory and research, 509-538. 2016.

CAWTHON, Stephanie; GARBEROGLIO Carrie Lou, (eds.) Research in deaf education: Contexts, challenges, and considerations. Oxford: Oxford University Press, 2017.

CLARK, Diane et al. The importance of early sign language acquisition for deaf readers. Reading \& Writing Quarterly, 32:2, 127-151, 2016.

CRIPPS, Jody; SUPALLA Samuel. The power of spoken language in schools and deaf students who sign. International Journal of Humanities and Social Science 2.16: 86-102. 2012.

ELHAGEEN, Adel Abdelfatah. Effect of interaction between parental treatment styles and peer relations in classroom on the feelings of loneliness among deaf children in Egyptian schools. Doctoral dissertation. Universität Tübingen. 2004.

ERBAS, Esra. Strategies that teachers use to support the inclusion of students who are deaf and hard of hearing. Master's Thesis. Indiana University. 2017.

FLAMSON, Thomas; BARRETT, Clark. The encryption theory of humor: A knowledge-based mechanism of honest signaling. Journal of Evolutionary Psychology 6.4: 261-281. 2008.

FLOOK, Lisa; REPETTI, Rena; ULLMAN, Jodie. Classroom social experiences as predictors of academic performance. Developmental psychology 41.2: 319-327. 2005.

GARNER, Randy. Humor in pedagogy and how ha ha can lead to ah ha: Physiological and psychological effects. College Teaching 54, 177-18. 2006. 
http://dx.doi.org/10.5902/1984686X38114

GLICKMAN, Neil. Culturally affirmative mental health treatment for deaf people: What it looks like and why it is essential. In GLICKMAN Neil.; GULATI Sanjay. (Eds.), Mental health care of deaf people: A culturally affirmative approach, 1-32. Mahwah, NJ: Erlbaum, 2003.

GONZALES, Maribel. Being and becoming a Deaf educator: the construction of Deaf educators' roles and pedagogies in Chilean Deaf schools. Unpublished doctoral dissertation. University of Bristol. 2017.

GUIMARÃES, Felipe Furtado; FINARDI, Kyria Rebeca; CASOTTI, Janayna Bertollo Cozer. Internationalization and Language Policies in Brazil: What is the Relationship? Revista Brasileira de Linguística Aplicada. 2019.

HALL, Stephanie. 'The Deaf Club is Like a Second Home': An Ethnography of Folklore Communication in American Sign Language. Doctoral dissertation. University of Pennsylvania. 1989.

HOFFMEISTER, Robert; CALDWELL-HARRIS, Catherine. Acquiring English as a Second Language via Print: The Task for Deaf Children. Cognition, 132, 229-242. 2014.

HOLCOMB, Thomas. Compartilhamento de informações: Um valor cultural universal dos surdos. In KARNOPP Lodenir; KLEIN Madalena; LUNARDI-LAZZARIN Márcia Lise (eds.) Cultura surda na contemporaneidade: Negociações, intercorrências e provocações, Canoas-RS: Editora da ULBRA. 139-149. 2011.

HUNG, Hsin-Ling. Factors associated with the attitudes of nondisabled secondary school students toward the inclusion of peers who are deaf or hard of hearing in their general education classes. Doctoral dissertation. The Ohio State University. 2005.

HUSS, John. Getting serious about humor: Attitudes of secondary teachers toward the use of humor as a teaching strategy. Journal of Ethnographic \& Qualitative Research 3, 28-36. 2008.

JOHNSON, Robert; LIDDELL Scott K.; ERTING. Carol J. Unlocking the Curriculum: Principles for Achieving Access in Deaf Education. Working Paper. p. 89-3. 1989. Accessed 29 March 2019: https://files.eric.ed.gov/fulltext/ED316978.pdf

JONAS, Peter. Laughing and learning: An alternative to shut up and listen. New York: Rowman \& Littlefield Education. 2009.

KEATING, Elizabeth; MIRUS Gene. Cross-modal conversations: Deaf children and hearing peers at school. Department of Applied Linguistics and TESL, UCLA: Crossroads of Language, Interaction, and Culture Conference, 3, 73-90. 2001.

$\mathrm{KOCH}$, Katherine A.; THOMPSON, Janna. Laughter filled the classroom: Outcomes of professional development in arts integration for elementary teachers in inclusion settings. Learning Disabilities: A Multidisciplinary Journal 22.2, 1-11. 2017.

KUNTZE, Marlon; GOLOS, Debbie; ENNS, Charlotte. Rethinking literacy: Broadening 
http://dx.doi.org/10.5902/1984686X38114

opportunities for visual learners. Sign Language Studies, 14, 203-224. 2014.

KURTZ, Laura; ALGOE, Sara. Putting laughter in context: Shared laughter as behavioral indicator of relationship well-being. Personal Relationships 22.4: 573-590. 2015.

KURZ, Kim; HAUSER Peter; LISTMAN Jason. Work-related resilience: Deaf professionals' perspectives. JADARA, 50(3), 88-109. 2016. Retrieved from

https://repository.wcsu.edu/jadara/vol50/iss3/1.

KUSHALNAGAR, Poorna et al. Retrospective basic parent-child communication difficulties and risk of depression in deaf adults. Journal of developmental and physical disabilities 29, 1: 25-34. 2017.

LADD, Paddy; GONÇALVES, Janie Cristine do Amaral. Culturas surdas e o desenvolvimento de pedagogias surdas. In KARNOPP Lodenir; KLEIN Madalena; LUNARDI-LAZZARIN Márcia Lise (eds.) Cultura surda na contemporaneidade: Negociações, intercorrências e provocações, Canoas-RS: Editora da ULBRA. 295-330, 2011.

LADD, Paddy. 2011. Deafhood and Deaf Educators. Some thoughts. In MATHUR Gaurav; NAPOLI, Donna Jo (eds.), Deaf around the World: The impact of language. Oxford: Oxford University Press, 372-382.

LAU, Tammy. et al. 2019. Oral language performance of deaf and hard-of-hearing students in mainstream schools. The Journal of Deaf Studies and Deaf Education.

doi.org/10.1093/deafed/enz012.

LADD, Paddy; GONÇALVES, Janie Cristine. A final frontier? How Deaf cultures and Deaf pedagogies can revolutionize Deaf education. In LEESON, Lorraine; VERMEERBERGEN Myriam (eds.), Working with the Deaf community: Deaf education, mental health and interpreting. Dublin: Interesource Group Ireland Limited, 9-33. 2012.

LAURSEN, Brett, et al. Friendship moderates prospective associations between social isolation and adjustment problems in young children. Child Development 78, no. 4: 13951404. 2007.

LEIGH, Irene. 2017. The complexities of deaf identities. In BAGGA-GUPTA Sangeeta; HANSEN, Aase Lyngvær; FEILBERG Julie (eds.) Identity revisited and reimagined, pp. 207-220. Springer, Cham, 2017.

LEVINGER, Miriam; ORLEV, Linoy. What deaf parents "Hear." Journal of International Social Research 1.4: 413-430. 2008.

LUCKNER, John; YARGER, Carmel. What's so funny? A comparison of students who are Deaf or hard of hearing and hearing students' appreciation of cartoons. American Annals of the Deaf 142.5, 373-378. 1997.

MAPEPA, Peter; MAGANO, Meahabo. Support to address barriers to learning for learners who are deaf. African Journal of Disability (Online) 7: 1-8. 2018. 
http://dx.doi.org/10.5902/1984686X38114

MIRUS, Gene; NAPOLI, Donna Jo. Developing language and preliteracy skills in deaf preschoolers through shared reading activities with bimodal-bilingual eBooks, Journal of Multilingual Education Research 8. 2018.

MIRUS, Gene; FISHER Jami; NAPOLI, Donna Jo. STICKY: Taboo topics in deaf communities. In Keith Allen (ed.) The Oxford handbook of taboo words and language, 140-159. Oxford: Oxford University Press. 2018.

MOURÃO, Claudio. Literatura Surda: Produções culturais de surdos em Língua de Sinais. Masters Dissertation. Department of Education, Federal University of Rio Grande do Sul. 2011.

MOST, Tova; INGBER Sara; HELED-ARIAM Einat. Social competence, sense of loneliness, and speech intelligibility of young children with hearing loss in individual inclusion and group inclusion. Journal of Deaf Studies and Deaf Education 17.2: 259-272. 2011.

MOST, Tova. Speech intelligibility, loneliness, and sense of coherence among deaf and hardof-hearing children in individual inclusion and group inclusion. Journal of Deaf Studies and Deaf Education 12.4: 495-503. 2007.

NATHAN LERNER, Miriam; FEIGEL Don. The heart of the hydrogen jukebox. New York: Rochester Institute of Technology. DVD. 2009.

NILSEN, Don. The language of humor: An introduction. Cambridge: Cambridge University Press. 2019.

NUGENT, Michael. The laughter of inclusion. University of Birmingham. Doctoral dissertation. 2016.

NUNES, Terezinha; PRETZLIK, Ursula; OLSSON, Jenny. Deaf children's social relationships in mainstream schools. Deafness \& Education International 3.3: 123-136. 2001.

OLSSON, Sylvia, DAG, Munir; KULLBERG, Christian. Deaf and hard-of-hearing adolescents' experiences of inclusion and exclusion in mainstream and special schools in

Sweden. European Journal of Special Needs Education 33, no. 4: 495-509. 2018.

PADDEN, Carol; RAMSEY Claire. Reading ability in signing deaf children. Topics in Language Disorders 18: 30-46. 1998.

PETERS, Cynthia. Deaf American Literature: From Carnival to the Canon. Washington, DC: Gallaudet University Press, 2000.

PERLIN, Gladis; STROBEL, Karin. Fundamentos na educação de surdos. Caderno

Pedagógico. Curso de licenciatura em Letras-Libras. Florianópolis: UFSC. 2008. 
http://dx.doi.org/10.5902/1984686X38114

PINHEIRO, Daiane. Produções surdas no YouTube: Consumindo a cultura. In KARNOPP Lodenir; KLEIN Madalena; LUNARDI-LAZZARIN Márcia Lise (eds.) Cultura surda na contemporaneidade: Negociações, intercorrências e provocações, Canoas-RS: Editora da ULBRA. 29-40, 2011.

QUADROS, Ronice Müller de; STUMPF, Marianne Recognizing Brazilian Sign Language: Sign language legislation and its outcomes. In MEULDER M.; MURRAY J.; Mckee R. (Eds.). Washington, DC: Gallaudet University Press. In press.

QUADROS, Ronice Müller de. Language policies and sign languages. In TOLLEFSON J.W.; PÉREZ-MILANS, M. (Orgs.). The Oxford Handbook of language policy and planning. 1e, Oxford: Oxford University Press. 1-22. 2018.

ROSENFELD, Malke. How I teach math \& dance at the same time. 2013. Accessed 6 April 2019: https://www.youtube.com/watch?v=i6qB2pTSRm8

ROSENFELD, Malke. Math on the move: Engaging students in whole body learning. Portsmouth, NH: Heinemann. 2016.

SANDERS, Danielle. Sign language in the production and appreciation of humor by Deaf children. Sign Language Studies 50, 59-72. 1986.

SCHAFFER, Karl; STERN, Erik; KIM, Scott. Math dance with Dr. Schaffer and Mr. Stern. Santa Cruz: MoveSpeakSpin. 2001.

SCHAFFER, Karl. Math and Dance- Windmills and Tilings and Things. Proceedings of Bridges 2012, 619-622. 2012.

SCHAFFER, Karl. Dancing deformations. Proceedings of Bridges 2014, Mathematics, music, art, architecture, culture, 253-260. 2014.

SCHMIDT, Richard; RICHARDSON, Michael. Dynamics of interpersonal coordination. In FUCHS, A.; JIRSA, VK (eds). Coordination: Neural, behavioral and social dynamics. Berlin: Springer-Verlag, 281-307. 2008.

SCOTT, Paul. Do Deaf children eat deaf carrots? In MATHUR Gaurav; NAPOLI, Donna Jo (eds.), Deaf around the World: the impact of language. Oxford: Oxford University Press, p359-366. 2011.

SEBANZ, Natalie.; KNOBLICH, Guenther. Prediction in joint action: What, when, and where. Topics in Cognitive Science 1: 353-367. 2009.

SEBANZ Natalie; BEKKERING Harold; KNOBLICH, Günther. Joint action: bodies and minds moving together. Trends in Cognitive Science 10: 70-76. 2006. 
http://dx.doi.org/10.5902/1984686X38114

SILVEIRA, Rosa Maria Hessel; SILVEIRA, Carolina Hessel; BONIN, lara Tatiana. Literatura infantil do século XXI: Surdez e personagens surdos. In KARNOPP Lodenir; KLEIN Madalena; LUNARDI-LAZZARIN Márcia Lise (eds.) Cultura surda na contemporaneidade: Negociações, intercorrências e provocações, Canoas-RS: Editora da ULBRA. 191-203. 2011.

SKYER, Michael. The pupil and the pedagogue: Dissensus in theorizing deaf visual pedagogy axiology in the biosocial paradigm. Dissertation. University of Rochester, 2018.

SUTTON-SPENCE, Rachel; NAPOLI, Donna Jo. Humour in sign languages: The linguistic underpinnings. Dublin: Trinity College, 2009.

SUTTON-SPENCE, Rachel. The role of sign language narratives in developing identity for deaf children. Journal of Folklore Research: An International Journal of Folklore and Ethnomusicology 47.3: 265-305. 2010.

SUTTON-SPENCE, Rachel; RAMSEY Claire. 'What we should teach Deaf Children: Deaf Teachers' Folk Models in Britain, the U.S. and Mexico' Deafness and Education International. 12/3, 149-176. 2010.

SUTTON-SPENCE, Rachel; BOYES BRAEM, Penny. Comparing the products and the processes of creating sign language poetry and pantomimic improvisations. Journal of Nonverbal Behavior, 37, 3, 245-280. 2013.

SUTTON-SPENCE, Rachel. Deaf Gain and Creativity in Signed Language. In BAUMAN Dirksen; MURRAY Joseph (eds), The New Normal: Deaf Gain and the Future of Human Diversity, Minneapolis: University of Minnesota Press, p257-277. 2014.

SWANWICK, Ruth; MARSCHARK Marc. Enhancing education for deaf children: Research into practice and back again. Deafness \& Education International 12.4: 217-235. 2010.

TAKALA, Marjatta; SUME, Helena. Hearing-impaired pupils in mainstream education in Finland: Teachers' experiences of inclusion and support. European Journal of Special Needs Education 33.1: 134-147. 2018.

THOMA, Adriana da Silva. Possibilidades de leitura da diferença surda no cinema. In KARNOPP Lodenir; KLEIN Madalena; LUNARDI-LAZZARIN Márcia Lise (eds.) Cultura surda na contemporaneidade: Negociações, intercorrências e provocações, Canoas-RS: Editora da ULBRA. 205-220. 2011.

TOMADA, Giovanna. et al. Friendship as a predictor of adjustment following a transition to formal academic instruction and evaluation. International Journal of Behavioural Development, 29, 314-332. 2005.

WANG, Ye; LEE, Chongmin; PAUL, Peter V. An understanding of the literacy levels of students who are deaf/hard-of-hearing in the United States, China, and South Korea. Educational Studies in Language and Literature, 10, 87-98. 2010. 
WEST, Donna. "We're the same. I'm deaf, You're deaf. Huh!" In MATHUR Gaurav; NAPOLI, Donna Jo (eds.), Deaf around the World: the impact of language. Oxford: Oxford University Press, 2011. 367-371.

XIE, Yu-Han; POTMESIL, Milon; PETERS, Brenda. Children who are deaf or hard of hearing in inclusive educational settings: A literature review on interactions with peers. Journal of Deaf Studies and Deaf Education, 19(4), 423-437. 2014.

\section{Notes}

1 "Na infância ficava a maior parte da vida brincando e assim, fui descobrindo significados dos jogos enquanto a boca era desconhecida... Na escola o mesmo acontece entre a boca e o brincar; todas as crianças e adolescentes têm direito de escrever, aprender e brincar, enquanto o indivíduo surdo continua escrevendo como imitação/cópia, pouco aprende e permanece muitas horas sem interagir”. (Mourão 2011, 36-37)

2 We use the term deaf, with a small "d", to cover a wide range of people, from those who have little to no access to sound to those who can function well in a hearing-speaking environment with a hearing aid or cochlear implant. In much past research a distinction was made between the labels Deaf and deaf, where the former indicated a cultural identity and the later indicated an audiological identity. Like some others in our field (Mirus, Fisher, and Napoli 2018), we break from the "d/D" convention in order to avoid the marginalization of deaf people who might not fit cleanly into one or the other. We do this not to deny sociocultural tendencies of those in deaf communities, but, rather, to recognize and include the various ways of being deaf.

${ }^{3}$ https://en.wikipedia.org/wiki/Common_Core_State_Standards_Initiative

${ }^{4}$ Many of our points rely on research through the last three to four decades or earlier. Rather than overwhelm the reader with dozens of citations, we prefer to give just a single recent citation that will send the interested reader to earlier ones.

5 4.7) garantir a oferta de educação bilíngue, em Língua Brasileira de Sinais - LIBRAS como primeira língua e na modalidade escrita da Língua Portuguesa como segunda língua, aos (às) alunos (as) surdos e com deficiência auditiva de 0 (zero) a 17 (dezessete) anos, em escolas e classes bilíngues e em escolas inclusivas, nos termos do art. 22 do Decreto no 5.626, de 22 de dezembro de 2005, e dos arts. 24 e 30 da Convenção sobre os Direitos das Pessoas com Deficiência, bem como a adoção do Sistema Braille de leitura para cegos e surdos-cegos; Our translation.

${ }^{6}$ We may note that deaf pedagogy is not only practised by deaf people. Hearing teachers may acquire the skills needed for Deaf pedagogy, but this requires them to be fully bilingual and to have a profound understanding of the needs and experiences of deaf children.

7 The complete list is: "family involvement, self-determination, extracurricular activities, friendships, social skills, self-advocacy skills, collaboration with early identification and early intervention service providers, high expectations, and preteach/teach/postteach content and vocabulary being learned in the general education classrooms" (Alasim and Paul 2018, 15).

8 Description of the workshops is available here: http://salaointernacionaldehumor.com.br/semcategoria/inscricoes-para-humor-na-sala-de-aula-2019/

\footnotetext{
${ }^{9}$ We can note that the audience reaction to the piece is laughter.

10 https://youtu.be/Gl3vqLeOyEE

11 https://youtu.be/kPXWu5UCTzk

12 https://www.facebook.com/watch/?v=1823725334333657
} 
http://dx.doi.org/10.5902/1984686X38114

\section{Correspondence}

Donna Jo Napoli - Swarthmore College, Pennsylvania - United States of America.

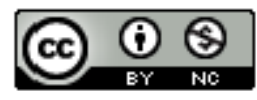

This work is licensed under a Creative Commons Attribution-NonCommercial 4.0 International (CC BY-NC 4.0) 